\title{
TU/e EmonOWEN

\section{Wavelength tuning of InAs quantum dots grown on InP (100) by chemical-beam epitaxy}

\section{Citation for published version (APA):}

Gong, Q., Nötzel, R., Veldhoven, van, P. J., Eijkemans, T. J., \& Wolter, J. H. (2004). Wavelength tuning of InAs quantum dots grown on InP (100) by chemical-beam epitaxy. Applied Physics Letters, 84(2), 275-277. https://doi.org/10.1063/1.1640474

DOI:

10.1063/1.1640474

Document status and date:

Published: 01/01/2004

\section{Document Version:}

Publisher's PDF, also known as Version of Record (includes final page, issue and volume numbers)

\section{Please check the document version of this publication:}

- A submitted manuscript is the version of the article upon submission and before peer-review. There can be important differences between the submitted version and the official published version of record. People interested in the research are advised to contact the author for the final version of the publication, or visit the $\mathrm{DOI}$ to the publisher's website.

- The final author version and the galley proof are versions of the publication after peer review.

- The final published version features the final layout of the paper including the volume, issue and page numbers.

Link to publication

\section{General rights}

Copyright and moral rights for the publications made accessible in the public portal are retained by the authors and/or other copyright owners and it is a condition of accessing publications that users recognise and abide by the legal requirements associated with these rights.

- Users may download and print one copy of any publication from the public portal for the purpose of private study or research.

- You may not further distribute the material or use it for any profit-making activity or commercial gain

- You may freely distribute the URL identifying the publication in the public portal.

If the publication is distributed under the terms of Article 25fa of the Dutch Copyright Act, indicated by the "Taverne" license above, please follow below link for the End User Agreement:

www.tue.nl/taverne

Take down policy

If you believe that this document breaches copyright please contact us at:

openaccess@tue.nl

providing details and we will investigate your claim. 


\title{
Wavelength tuning of InAs quantum dots grown on InP (100) by chemical-beam epitaxy
}

\author{
Q. Gong, ${ }^{\text {a) }}$ R. Nötzel, P. J. van Veldhoven, T. J. Eijkemans, and J. H. Wolter \\ eiTT/COBRA Inter-University Research Institute, Eindhoven University of Technology, \\ $5600 \mathrm{MB}$ Eindhoven, The Netherlands
}

(Received 18 September 2003; accepted 18 November 2003)

\begin{abstract}
We report on an effective way to continuously tune the emission wavelength of InAs quantum dots (QDs) grown on InP (100) by chemical-beam epitaxy. The InAs QD layer is embedded in a GaInAsP layer lattice matched to InP. With an ultrathin GaAs layer inserted between the InAs QD layer and the GaInAsP buffer, the peak wavelength from the InAs QDs can be continuously tuned from above $1.6 \mu \mathrm{m}$ down to $1.5 \mu \mathrm{m}$ at room temperature. The major role of the thin GaAs layer is to greatly suppress the As/P exchange during the deposition of InAs and subsequent growth interruption under arsenic flux, as well as to consume the segregated surface In layer floating on the GaInAsP buffer layer. (C) 2004 American Institute of Physics. [DOI: 10.1063/1.1640474]
\end{abstract}

Self-assembled InAs quantum dots (QDs) grown on InP substrates attract more and more efforts due to their longwavelength emission, as well as the potential properties of zero-dimensional structures for optoelectronic device applications. ${ }^{1-3}$ InAs/InP QDs are very promising for QD lasers and semiconductor optical amplifiers operating in the $1.55 \mu \mathrm{m}$ wavelength range for fiber optical telecommunication systems. However, it is still a challenge to tune the emission wavelength to $1.55 \mu \mathrm{m}$ since InAs/InP QDs usually exhibit emission above $1.6 \mu \mathrm{m}$ at room temperature (RT). ${ }^{1}$ Recently, emission at $1.55 \mu \mathrm{m}$ has been observed from InAs quantum dashes grown on $\operatorname{InP}(100){ }^{4}$ These quantum dashes, however, are quasi-one-dimensional instead of zerodimensional structures such as QDs. A promising method has been proposed for InP (311)B substrates to achieve InAs QDs with emission at $1.55 \mu \mathrm{m}$ by postgrowth annealing. ${ }^{2}$ But, for InAs QDs on InP (100), no effective way has been reported to reduce the emission wavelength. In this letter, we present a method to tune the emission wavelength of InAs/ $\operatorname{InP}(100)$ QDs embedded in lattice matched GaInAsP which is the waveguide core material in InP-based devices. By inserting an ultrathin GaAs layer [0.3-2.5 monolayers (MLs)] between the QD layer and the GaInAsP buffer, continuous wavelength tuning from above 1.60 to $1.5 \mu \mathrm{m}$ at RT is demonstrated by varying solely one growth parameter, i.e., the GaAs layer thickness. The thin GaAs interlayer plays an important role in suppressing the As/P exchange and consuming the segregated surface In layer, leading to a drastic reduction of the emission wavelength and improvement of the optical quality of the InAs QDs in GaInAsP.

The samples were grown by chemical-beam epitaxy using trimethylindium, triethylgallium, $\mathrm{AsH}_{3}$, and $\mathrm{PH}_{3}$ as precursors. The $\mathrm{AsH}_{3}$ and $\mathrm{PH}_{3}$ gases were thermally decomposed in a high-temperature injector at $900^{\circ} \mathrm{C}$. The $\mathrm{InP}$ (100) substrates, misoriented by $2^{\circ}$ toward (110), were mounted by indium on Mo blocks, and degassed in the buffer chamber at $200{ }^{\circ} \mathrm{C}$ for $30 \mathrm{~min}$ before being transferred into the growth chamber. The grown structure consists of a 200

${ }^{a)}$ Electronic mail: q.gong@tue.nl $\mathrm{nm}$ InP buffer, $100 \mathrm{~nm}$ lattice-matched GaInAsP $\left(\lambda_{g}\right.$ $=1.29 \mu \mathrm{m})$, a thin GaAs layer with varied thicknesses from 0 to $2.5 \mathrm{MLs}$, the InAs QD layer, and a $100 \mathrm{~nm}$ GaInAsP cap layer. The InAs QD layer was formed by nominal deposition of $3.2 \mathrm{MLs}$ InAs at a rate of $0.4 \mathrm{ML} / \mathrm{s}$, and $5 \mathrm{~s}$ growth interruption under As flux. A second QD layer was grown under the same conditions on the surface for atomic force microscopy (AFM) measurements. The growth temperature was $500^{\circ} \mathrm{C}$ for all layers. After growth, the samples were cooled down quickly by cutting off the power, and taken out for AFM and photoluminescence (PL) measurements. For PL, the samples were excited by a Nd:YAG laser in a cryostat $(4.8 \mathrm{~K})$ with an excitation power density of $256 \mathrm{~mW} / \mathrm{cm}^{2}$. AFM measurements were carried out in tapping mode.

The low-temperature PL spectra of the InAs QDs with GaAs interlayers of different thicknesses are shown in Fig. 1(a). For the reference sample without GaAs layer, the PL emission from the InAs QDs is centered at $1556 \mathrm{~nm}$ with a linewidth of $44 \mathrm{meV}$. With an increase of the GaAs layer thickness, the PL peak continuously shifts to a shorter wavelength and reaches $1401 \mathrm{~nm}$ when 2.5 MLs GaAs are inserted between the InAs QD layer and the GaInAsP buffer, as shown in Fig. 1(b). The wavelength reduction gradually saturates for GaAs thicknesses around 2.5 MLs. The thin GaAs layer, moreover, reduces the PL linewidth from 44 to $35 \mathrm{meV}$ when the GaAs layer thickness is above 0.8 MLs. In addition, the peak intensity increases with the insertion of the GaAs layer. Therefore, applying a thin GaAs layer to modify the GaInAsP surface for InAs QD growth is a promising way to tune the emission wavelength of InAs QDs, simultaneously improving their optical properties. The PL spectra measured at room temperature of the InAs QDs with GaAs interlayers are shown in Fig. 2. The PL line centered at 1.29 $\mu \mathrm{m}$ is from the GaInAsP barrier. With 1.2, 1.9, and 2.5 MLs GaAs interlayer, the PL peak from the InAs QDs is, respectively, centered at 1560, 1520, and $1496 \mathrm{~nm}$. Clearly, by inserting an ultrathin GaAs interlayer, the emission wavelength at RT of the InAs QDs can be widely tuned, covering the $1.55 \mu \mathrm{m}$ range. The PL efficiency at RT of the InAs QDs 
(a)

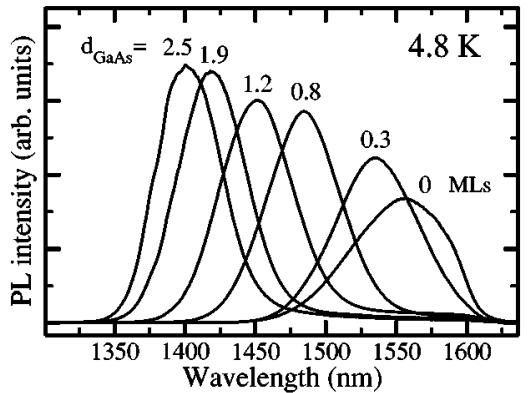

(b)

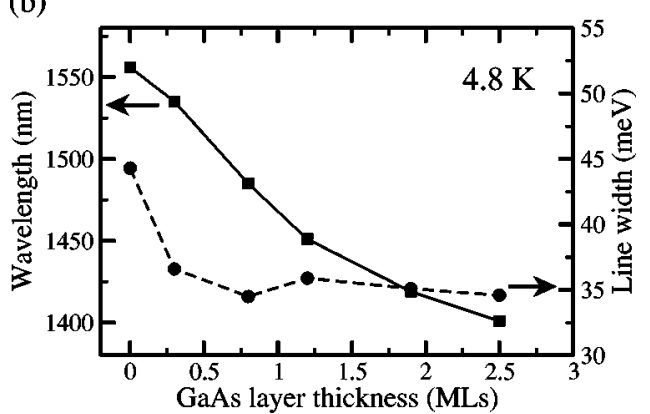

FIG. 1. (a) PL spectra at $4.8 \mathrm{~K}$ of the InAs QDs on lattice matched GaInAsP with thin GaAs interlayers of different thicknesses between the InAs QD layers and the GaInAsP buffer. The dependence of the PL peak wavelength and linewidth on the GaAs layer thickness is shown in (b).

is always higher compared to that of the GaInAsP barriers with run-to-run fluctuations due to nonradiative recombination centers. Similar to InAs QDs on GaAs, the PL linewidth undergoes a minimum around $90 \mathrm{~K}$ due to thermally activated carrier redistribution from small to large QDs. The linewidth at RT (when the carrier distribution in the small and large QDs becomes equal), however, exceeds that at low temperature, indicating a generally wider size distribution of the InAs QDs on GaInAsP/InP compared to that achieved for InAs QDs on GaAs. ${ }^{5}$

The morphology of the InAs surface QDs grown on the thin GaAs interlayers deposited on GaInAsP are shown in Fig. 3. InAs QDs are formed on all the samples. The average QD height is found to decrease with the increase of the GaAs

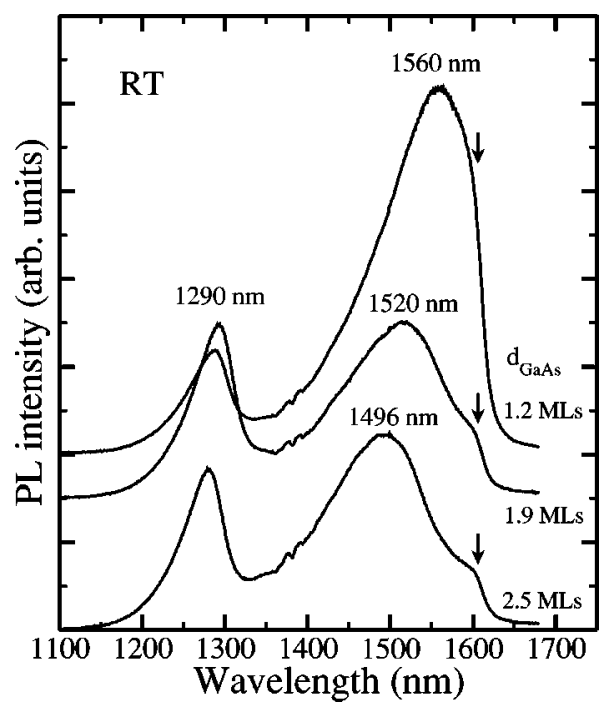

FIG. 2. RT PL spectra of the InAs QDs with 1.2, 1.9, and 2.5 MLs GaAs inserted between the InAs QD layer and the GaInAsP buffer. The arrows at

$1.6 \mu \mathrm{m}$, mark the detection limit of the cooled InGaAs detector. InAs layer and the GaInAsP buffer.
Downloaded 12 Dec 2007 to 131.155 .108 .71 . Redistribution subject to AlP license or copyright; see

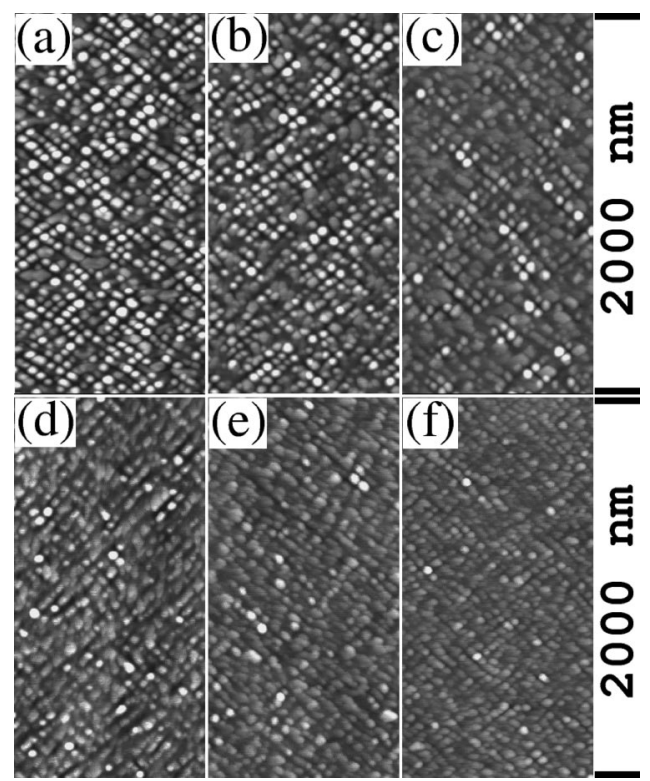

FIG. 3. AFM images of the InAs QDs on lattice matched GaInAsP with thin GaAs interlayers between the InAs QD layer and GaInAsP buffer. The GaAs layer thickness is (a) 0 , (b) 0.3 , (c) 0.8 , (d) 1.2, (e) 1.9, and (f) 2.5 MLs. The black-to-white height contrast is $10 \mathrm{~nm}$ for $(\mathrm{a}-\mathrm{c})$ and $5 \mathrm{~nm}$ for $(\mathrm{d}-\mathrm{f})$.

layer thickness. Together with the PL blueshift this provides a first indication that the GaAs interlayer suppresses the As/P exchange (known to raise the aspect ratio of InAs/InP QDs ${ }^{6}$ and redshift the PL emission) and reduces the amount of floating In at the surface, resulting in lower and smaller InAs QDs.

In order to clarify the effect of the thin GaAs layer on the growth of InAs, samples with 1.6 MLs InAs embedded in GaInAsP have been studied. Here, the InAs thickness is below the critical one for QD formation to exclude complications due to the QD formation process. For comparison, two samples were grown under the same conditions, with and without a 1.2 MLs GaAs interlayer. The PL spectra of these samples are shown in Fig. 4. A broad emission peak with linewidth of $45 \mathrm{meV}$ is observed for the sample without GaAs interlayer, which is much broader than that commonly obtained for quantum wells. Again, the thin GaAs interlayer inserted between the InAs layer and GaInAsP buffer greatly improves the optical properties. The PL linewidth is reduced from 45 to $12.8 \mathrm{meV}$, the PL peak intensity is increased, and

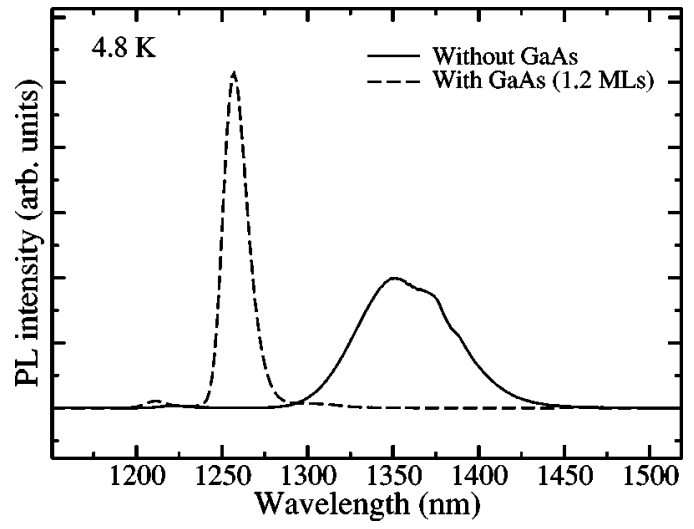

FIG. 4. PL spectra at 4.8 K of 1.6 MLs InAs embedded in GaInAsP without (solid line) and with (dashed line) 1.2 MLs GaAs interlayer between the

InAs layer and the GaInAsP buffer. 
the PL peak shifts to shorter wavelength. It is well established that the exchange of group- $\mathrm{V}$ elements, i.e., As and $\mathrm{P}$, in the epitaxy on InP substrate is a very critical issue for thin film deposition, being the main reason for rough interfaces, nonuniform layers, PL broadening and redshift. ${ }^{6-9}$ Compared to lattice matched layers, for InAs deposited on GaInAsP, the influence of the As/P exchange might be even enhanced due to the high compressive strain. By adjusting the gas switching sequence, this can not be avoided since considerable As/P exchange occurs already during the growth of InAs. Our results, thus, confirm that deposition of the thin GaAs interlayer provides an effective solution to suppress the As/P exchange by modifying the surface properties before the InAs growth. This can be understood from the chemical bond strength difference between As and P to the group-III elements. In - As bonds (with bond strength of $48.0 \mathrm{kcal} / \mathrm{mol}$ ) are slightly more stable than $\mathrm{In}-\mathrm{P}$ bonds $(47.3 \mathrm{kcal} / \mathrm{mol}){ }^{10}$ favoring the replacement of $\mathrm{In}-\mathrm{P}$ by $\mathrm{In}-\mathrm{As}$ bonds, i.e., the substitution of $\mathrm{P}$ by As atom on InP. On the contrary, the $\mathrm{Ga}-\mathrm{P}$ bond $(54.9 \mathrm{kcal} / \mathrm{mol})$ is by far more stable than the $\mathrm{Ga}$ - As bond $(50.1 \mathrm{kcal} / \mathrm{mol})$, counteracting the substitution of P by As on GaAs. The thin GaAs layer, therefore, greatly protects the $\mathrm{P}$ atoms on the GaInAsP surface from substitution by As. As a result, the PL from the thin InAs layer is narrower and shifted to a shorter wavelength. A further reason for the PL blueshift, however, might be related to the floating layer of segregated In at the surface, which is normally observed during epitaxy of $\operatorname{In}(\mathrm{Ga}) \mathrm{As} .{ }^{11,12}$ The GaAs layer may consume the floating In layer to form InGaAs, thereby reducing the amount of In incorporated into the InAs layer. Fortunately, both effects caused by the thin GaAs layer, suppressing the As/P exchange and consuming the surface In, reduce the emission wavelength of the InAs layer and, consequently, the InAs QDs. Moreover, the thin GaAs interlayer greatly improves the material optical quality.

In summary, an effective method to tune the emission wavelength of InAs QDs embedded in GaInAsP on InP (100) substrates has been demonstrated. By depositing an ultrathin GaAs layer on the GaInAsP buffer before the InAs QD growth, the PL peak wavelength can be continuously reduced with the increase of the GaAs layer thickness from 0 up to 2.5 MLs. A wide wavelength range from above $1.6 \mu \mathrm{m}$ to below $1.5 \mu \mathrm{m}$ at RT can be reproducibly accessed by this method, which will pave the way toward InAs/InP QD device applications for fiber optic telecommunication systems operating in the $1.55 \mu \mathrm{m}$ wavelength range.

${ }^{1}$ C. Ni. Allen, P. J. Poole, P. Marshall, J. Fraser, S. Raymond, and S. Fafard, Appl. Phys. Lett. 80, 3629 (2002).

${ }^{2}$ C. Paranthoen, N. Bertru, O. Dehaese, A. Le Corre, S. Loualiche, B. Lambert, and G. Patriarche, Appl. Phys. Lett. 78, 1751 (2001).

${ }^{3}$ J. Brault, M. Gendry, G. Grenet, G. Hollinger, Y. Desieres, and T. Benyattou, J. Cryst. Growth 201, 1176 (1999).

${ }^{4}$ R. Schwertberger, D. Gold, J. P. Reithmaier, and A. Forchel, J. Cryst. Growth 251, 248 (2003).

${ }^{5}$ I. Mukhametzhanov, Z. Wei, R. Heitz, and A. Madhukar, Appl. Phys. Lett. 75, 85 (1999).

${ }^{6}$ S. Yoon, Y. Moon, T.-W. Lee, E. Yoon, and Y. D. Kim, Appl. Phys. Lett. 74, 2029 (1999).

${ }^{7}$ R. P. Schneider, Jr. and B. W. Wessels, Appl. Phys. Lett. 57, 1998 (1990).

${ }^{8}$ K. Ozasa, Y. Aoyagi, Y. J. Park, and L. Samuelson, Appl. Phys. Lett. 71, 797 (1997).

${ }^{9}$ T. Y. Wang, E. H. Reihlen, H. R. Jen, and G. B. Stringfellow, J. Appl. Phys. 66, 5376 (1989).

${ }^{10}$ T. Anan, S. Sugou, K. Nishi, and T. Ichihashi, Appl. Phys. Lett. 63, 1047 (1993).

${ }^{11}$ J. M. García, J. P. Silveira, and F. Briones, Appl. Phys. Lett. 77, 409 (2000).

${ }^{12}$ J.-M. Gerard, Appl. Phys. Lett. 61, 2096 (1992). 